\title{
The Relevance Of The Concept Of Saving The Perspective Of The Shari'ah Of The Prophet Yusuf AS To The Shari'ah Of The Prophet Muhammad SAW
}

\author{
Ahmad Muhajiri), Asmuni2 ${ }^{2 *}$, Tuti Anggraini ${ }^{3)}$ \\ 1) Universitas Al-Azhar, \\ 2,3) Universitas Islam Negeri Sumatera Utara \\ *Coresponding Author \\ Email : amuhajir891@gmail.com
}

\begin{abstract}
Saving is an activity to prepare future costs so that all the necessities of life remain stable and orderly. Mental preparation before saving is to be frugal. Without this it is very difficult to save. Various methods of saving, including saving at home, saving in the bank. The author examines the method of saving the number of perspectives in the time of the Prophet Yusuf(as). that is, setting aside more of the earth's savings than allocating consumptive needs. As a result, when a famine occurs / economic crisis, the savings can meet the conditions of a famine that are met in a stable and orderly manner. Saving for 7 years, the savings can meet the needs for the next 7 years during famine. Writing this with the literature method, which uses the approach of interpretive studies and then analyzed and applied in the present age. The results of the analysis that the theory of saving is a quota of more savings the money from income than expenditure.
\end{abstract}

Keywords: Saving, Age of the Prophet Yusuf

\section{INTRODUCTION}

Saving money is a part of prepare for the planning of the future will come at once to face the things that are not desirable. Technically, a way of saving money that is set aside property owned at this time to meet the needs of the future. Financial experts often say that the way terbijak to save that pick up at an advance of $10 \%-20 \%$ of revenue. Means the money saved is not the rest of the consumption, but the allocation is planned in advance as taken before the fulfillment of the needs of consumption. Islam prohibits the consumption of excessive and hoarding wealth, hence the funds need to be organized with a good way to continue to grow and sustainable. The asset will not be consumed, but should be saved or invested. For expenses that are consumptive, named living, Ibn Sina argues that includes all the shopping for the needs of human life, especially food, shelter, household spending, shopping for a wife, and shopping for the kids. Because that stuff a lot and have different sizes, Ibn Sina advised that in all the shopping konsutif it should be efficient and simple, do not overdo it and also need. As for the size to set a simple and efficient it is the general opinion. But there is also a shopping mall that has its own size who can not use the size of the public opinion. In this case it is recommended to wear the consideration yourself healthy by sticking to the principle of simple and efficient.

\section{RESEARCH METHODS}

This research uses descriptive qualitative research is a type of research that do not use the system statistics or calculations. Types of qualitative research aims to reveal a phenomenon accurately with the existing rules and to be the primary key of a research instrument. What is 
meant by the researchers of the key instruments that only focus on the research topic with how to select the speaker as the basis of the information data, collect data, assess data quality, data analysis, interpreted to conclude the data.

In this activity, the researcher used secondary data or research library. Secondary Data is the data obtained by the researcher through a wide variety of literature that already exists. 9 Types of secondary data used in this research is library research (library research).10 Purpose the authors use secondary data sources with the type of library research is to help resolve a problem that requires the study of literacy in detail, in addition, this type of research is useful as a reference accurate.

\section{RESULTS AND DISCUSSION}

\section{The perspective of the time of the prophet Yusuf as. in terms of saving money.}

The perspective of the time of the prophet Yusuf as. in terms of saving, look at verse-the verse of saving the macro (state duty). Although the macro, this can be applied in the micro (individual). The following (QS. Yusuf 47-48 :

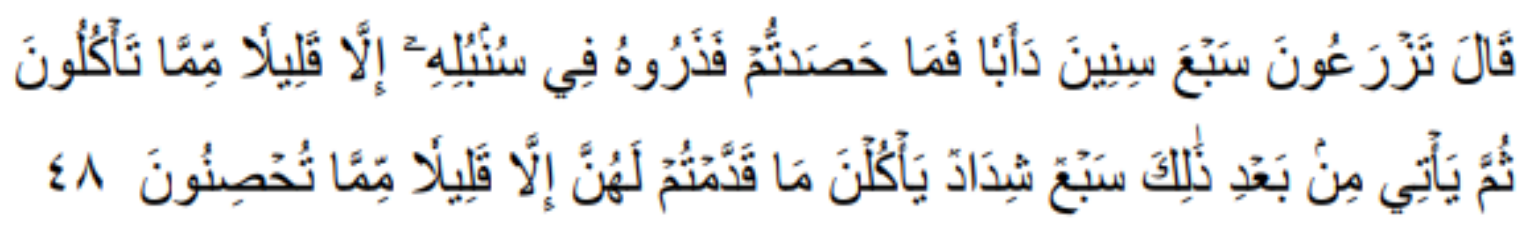

"He (Yusuf) said, "So you cultivate during the next seven years (in a row) as usual; then what you reap you shall leave it in the stem, except for what you eat.Then after that will come seven (years old) who is very difficult, which spend what you save to deal with (a difficult year), except a little of what (wheat germ) that you save" ( QS. Yusuf : 47-48).

Hear the question asked the name of the king and leaders of community leaders that, without waiting for the after with the expectation of the questioner directly to him, that the Prophet Yusuf. said, as if to communicate with all of them. Therefore, he uses the plural, "Dream ordered you, o people of Egypt, through the king, so you're constantly farming for seven years as you grow crops, namely by considering the state of the weather, the types of crops grown, irrigation and so on or for seven years in a row with intent. Then what you reap from the harvest of all time that you should leave it in the head so he remains fresh no broken because usually the wheat of Egypt only survive two more years of this expert opinion tafsir Abu Hayyan. Except for a slight namely that it does not need you to save and leave in the head that you need to eat. Then, after a period of seven years, there will come seven years of a very difficult due to the occurrence of famine in the whole country who spend what you save to deal with it, namely to face the difficult years that are symbolized by the seven heads of grain, dry it except a little of what is, namely wheat germ, which you save. That's the meaning of a dream of the king.

The prophet Yusuf. understand the seven cows as a seven-year period of agriculture. Not so, because the cow is used hijack, then the cow is a symbol of fertility, are emaciated cow is a difficult period in the field of agriculture, namely a period of famine. Grains of wheat the symbol of food available. Each grain with a year. And vice versa. Tabatabai expert interpretation is judged that such a dream is a hint to the king to take measures to save its 
people from a food crisis. That he should put forward seven cows to be eaten by the cows, skinny and store most of the food that has been harvested fixed in the head to keep them fresh and not damaged by weather factors and so on. Thus, the Prophet Yusuf convey what will happen and how to deal with it, that he should strive to plant and save the bulk of the harvest.

Description above QS Yusuf : 47-48 there in the previous verses as the background. Described starting from verse 43 to 46, that the king in a dream which is very magical and very mengelisahkan his heart. Yet ever the king had a dream as it was during his life. Then it collects all those ingenious clever, draftsman-draftsman weaving and rulers of his kingdom, then the king said :

"Verily I saw seven cows female fat being eaten by seven thin, and seven grains of green and the other dry-dry, those people are leading! Tell me about the meaning of my vision, if you can interpret dreams. "They replied, It was a dream-a dream that is empty and not our concerns those dreams are empty people who are experts"

As it turned out, none of them can give the veil king's dream. Then there was a flush of the king's garden which tells of a young man who is in prison has a depth of knowledge, Yusuf name. The king sent a handyman flush the garden was to meet Yusuf. When meeting with Yusuf, artisan flush the garden asks about the dream of the king. Therefore, in SURAH Yusuf verse 47 of the above. That is to cultivate seven years as usual. Then what you harvest leave still ditangkainya, except a little to eat that for food reserves when it comes the difficult period for seven years. And Yusuflah that successfully explained the veil of the dream of the king with clear and correct. This is the principle that explains the importance of setting aside property at time of abundance for use in times of shortage.

Tafsir of Surah Yusuf verse 58-61.

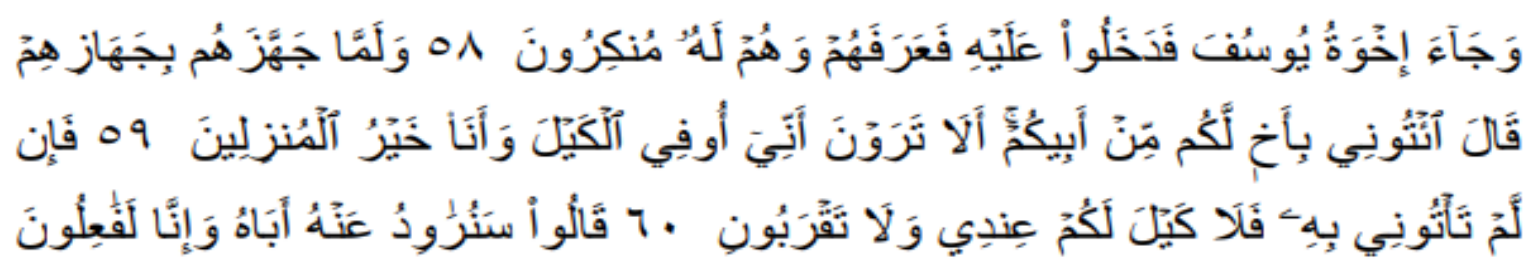

"And there came Yusuf's brothers, and then they get to him, then, he directly knew them, are they against her completely foreign. And when he prepared for them the ingredients of their food, he said, "Bring your brother to me, brother you are permanent with you. Did you not see that I'm perfecting measuring and I are the best reception? If you don't bring me, then you will not get the measuring for you from me and do not come near me, "They said, "We will persuade his father and indeed, we will be the executor-executor" (Q.S Yusuf : 58 - 61)

Long running time. Now the dream of the king proved in reality. Famine hit areas of Egypt and surrounding areas. Ya'kub as. along with the children who live not far from Egypt, namely in Palestine. Experiencing difficult times. They hear that Egypt's government distributed food to people need or sell it at a very cheap price. Presumably ration of it is individual. Because it's, ya'kub as. ordered all of his son heading to Egypt, except Benjamin / siblings Yusuf. The verses above suggest that Yusuf. directly involved and active in the efforts of the division of food and supervision, not delegated work to his subordinates. This is evident 
from his meeting with his brothers and sisters in the location of the division of it as well as the influx of them to meet him at that place. What was done to Yusuf. this shows how big of a responsibility for him. And it is also a very valuable lesson for anyone in the line of duty.

\section{The Implementation Of The Business Based On The Teachings Of The Prophet}

The messenger of allah reached the success of his business not influenced by the hard work that he did, in addition to the Messenger of allah is very professional in managing marketing in her business. The cornerstone of the Messenger of allah the most important in running a business and daily life that is based on the command that is contained in the Qur'an. A successful business not in spite of some things which must be done based on trust which is related to ethics. The implementation of the business based on the Qur'an, especially in the sale and purchase have a few rules which if business is done in cash, the parties involved in the business should be based with the wishes of each or the absence of coercion. Then, if the business is done in cash, the parties involved should be recorded transactions made and there must be witnesses, it is done so that no one party is lying about the nominal or weight scales in the transaction because everything that is done by humans are always in the watch by Allah SWT. The main purpose of the Prophet in trade is to spread the dawah to anyone in the community around the area of the Arab countries are still many who have bad behavior. So with the proselytizing of the Prophet when to trade, make an appropriate means to provide advice to through the activities of men. Not until there dakwah done, but he appealed to his people to carry out da'wah through the way of human relations such as trade and how to better the other, see current conditions in the where a lot of people have a moral crisis, especially in the business to justify all the way to get profit then preaching in entrepreneurship is also very important to be delivered.

\section{Discussion}

(Q.S Yusuf : 47) explained mainly on the editorial Fi Sumbulihi/stalk. A content tree that is left on the stem and stored will be more secured. If the fruit on the break up of the stems and stored, the security is not strong. The lessons implied by the method of storage of fruits that are not detachable from the stem. Namely human save money, storage of any assortment. There is a piggy bank in the form of cans/clay, wallet which is stored in the wardrobe, saving gathering, savings in the bank, and others. Suppose that the saving in the bank amounting to Rp 1.000.000,- and in the piggy bank of the cans also Rp 1.000.000,-. The owner of such savings if going to take that one in the bank tend to think many times, due to the complexity of the rules. Different with owners who have a piggy bank cans when going to take the money tend to be direct in the open, because there are no complicated rules.

Expenses are mandatory / consumptive as possible to budgeted. In other words, a lot more storage in the appeal with the expenditure. Then the effect at a time when no source of income, such savings becomes the source of his income. Described at the time of the Prophet Yusuf as. his people worked for seven years and his income is to be stored/ditabungkan more than for food. As a result, when a famine for seven years, the people have no source of income, unless the role/function of the deposits of the former can be as a source of income during the famine which is seven years. An example of the monthly salary of Rp 800.000,-- Separu from 400.000. stored a minimum of 450,000. the budget make a living to 350,000 in a single month. 
Then per day to $350,000: 30=11,666$ rounded 11.650 . when the moon is next idle can still be budgeted 11.650 in the day.

The story of the prophet Yusuf as. is save the results of the earth is not a currency. On the other hand, there is a ban on hoarding goods. The second thing is practice the same, but the goal is different. What is forbidden is no intention and accidentally hoard of fun for price/ for profit. Islam prohibits the hoarding or things that hinder the distribution of goods to the consumer. Hoard is to buy goods in large quantities then save it with the intent to sell them at high prices. Hoarding is prohibited so that the treasure does not circulate only among certain people as Islamic mission. A hadith which :

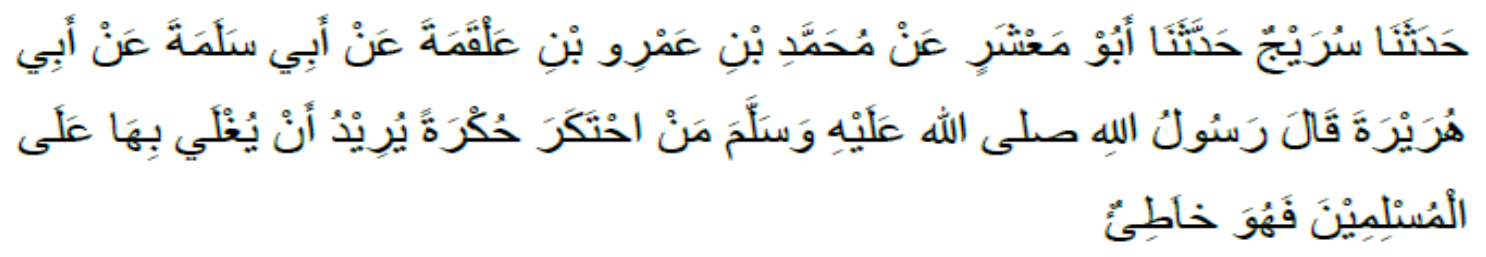

"Had told Suraij had told Abu Ma'syarin from Muhammad Ibn ' Umar Ibn 'Alqamata of Abi Salamah dari Abi Hurairah said, "the Messenger of allah has said: anyone Who does hoarding to get the price of the most high, with the purpose of outwit the muslims then ternasuk wrong doings."

The hadith implies that the act is wrong, namely to storethe of regulation buy sell or trade in the economic system of Islam based on the qur'an and Hadith

At the moment (the people of the prophet Muhammad SAW) is different to the time of the prophet Yusuf as. the people of prophet muhammad SAW in addition to the expenses for the needs of the consumer are also spending the treasures that are mandatory, such as the zakat mal and al, and go to hajj which is a pillar of Islam to 5. The time of the prophet Yusuf as seen in Q.S Yusuf verses 47-48 expenses for food only. For the application of the method of savings when the prophet Yusuf allegedly was running water. A tap on the cue above verse is to save the need for food.

Analysis on the surah yusuf verse 58-61, that the storage function of the earth for 7 years in subsidies / share to people who need it when it actually happens famine. The economy of the time was very welfare of the people. It is not separated from the puppet masters of the Prophet Yusuf as. a very clever organize, plan, allocate the results of the earth. Today with the presence of Banks, the function and its role is also very welfare of the people.

\section{CONCLUSION}

Saving money is a planned program has a vision and mission, namely the saving Principle should be applied so that the savings program success. Type of goods to be stored on the study of the tafsir of surah Yusuf verses 47-48 is the fruit / result of the earth. In order of deposits / savings as a source of income to meet the needs of the famine in the time of the prophet Yusuf as. The cue is also still applied in the shari'ah of Prophet Muhammad SAW in the times of now to save money. Because money is a tool of exchange. In order of deposits / savings not only to the famine but for both, the cost of higher education, the cost of emergency unpredictable, and others. Financial institutions such as the bank functions also vary, one of which is the fund for economic development, it is similar in function to a savings in the time of prophet Yusuf. 


\section{REFERENCES}

Muslim, Shahih Muslim, Takhrij Hadis Digital

Nur Diana, Ilfi, Hadis-Hadis Ekonomi, Malang: UIN Maliki Press, 2012 S

hihab, M. Quraish, Tafsir al-Mishbah, Jakarta: Lentera Hati, 2009

-------------, Wawasan Al-Qur'an, Bandung: Mizan, 1996 Sujarweni, V. Wiratna, Manajemen Keuangan, Yogjakarta: PT. Pustaka Baru,

Suwikyo, Dwi, Ayat-Ayat Ekonomi, Yogyakarta: Pustaka Pelajar, 2010

Widowati, Ayun Sekar, Pengaruh Pengetahuan Produk Tabungan, Reputasi Bank, dan Persepsi Nasabah mengenai suku bunga simpanan terhadap keputusan menabung nasabah, Yogyakarta: Sekripsi, 2018

Zaky Al Kaaf, Abdullah, Ekonomi Dalam Perspektif Islam, Bandung: CV Pustaka Setia, 2002 